\title{
Solar Energy: Peaceful Hope Among Nations
}

Flory Anette Dieck-Assad, Tecnológico de Monterrey, Mexico Eduardo Carbajal-Huerta, Tecnológico de Monterrey, Mexico

\begin{abstract}
The CFE (Federal Electricity Commission), the state-owned company supplier of electricity in Mexico has to face the greatest challenge in its history: increase the electric power required for economic development; this would mean having to add an additional electricity capacity of 57,122.3 MW (Mega Watts) for 2030. The Mexican Secretary of Energy expects that $37.8 \%$ will be provided by conventional technologies, and $62.2 \%$ through clean technologies. Thus, there are 35,530.07 MW of additional capacity pending on future clean projects. This case shows the financial and ethical dilemmas in order to achieve these goals with a focus on sustainability, seeking to minimize emissions of greenhouse gases. Aging coal plants, cheap natural gas, and a downward trend in the price of renewable energy, are signs of a dramatic structural change in the world electricity sector. These trends are likely to hold in the future where solar technologies have made up a bigger share, and regardless of their small percentage of participation in the energy mix, solar energy could reveal a surprising new story for the world. Facing CFE's challenge, this case explores the role that solar photovoltaic energy could play where the sky is the limit.
\end{abstract}

Keywords: Electricity Capacity; Renewable Energy; Solar Photovoltaic Energy Sustainability

\section{INTRODUCTION}

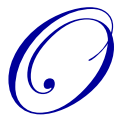

n October 25, 2016, the Mexican Secretary of Energy, Pedro Joaquin Coldwell, appeared before Congress stating that "we are working in the energy transition towards a low carbon emission economy" (Canal del Congreso, 2016). As promised on that day, the study that could help Mexican legislators in Congress to envision the scenario for the generation of electric power in Mexico by 2030 was published on December 30, 2016 (SENER, 2016a).

Jaime Francisco Hernandez-Martinez, the Director of the CFE (Federal Electricity Commission), the state-owned company supplier of electricity in Mexico, faces the greatest challenge in CFE's history: increase the electric power required for economic development and secure the supply of electricity with a sustainable approach, according to SENER's scenario submitted to the Mexican Congress (SENER, 2016a).

\section{STATISTICS SUBMITTED TO CONGRESS}

The scenario for electricity generation sent to Congress, aimed at identifying the path of growth for the electricity sector in Mexico toward 2030, which could definitely lower $\mathrm{CO}_{2}$ emissions, and is summarized in Table 1 (SENER, 2016a).

The Director of the CFE, Jaime Francisco Hernandez-Martinez, agreed with the legislators and the Secretary of Energy (SENER) that it was essential to walk through the path of renewable energy, but he questioned the fact that the scenarios gave more importance to the growth of wind energy compared to solar energy. If wind energy would increase its participation from $4.1 \%$ to $13.8 \%$ in total capacity in 2030 compared with 2015 , would it be possible to envision a more dramatic change in the estimated participation of solar energy that now is estimated to grow from $0.25 \%$ in 2015 to $6.3 \%$ in 2030 ? Will solar energy surpass the $6.3 \%$ participation by 2030 ? 
Reviewing SENER's statistics, he thought about the importance to explore the role that solar photovoltaic energy (PV) could play in this scenario, due to the recently published 2016 statistics of solar energy growth in the U.S. where $39 \%$ of new generation capacity came from PV (SENER, 2016a). The U.S. Solar Energy Industries Association projected to triple its generation capacity in the next five years, because for solar energy, indeed, the sky is the limit (SEIA, 2017a).

Table 1. Official Scenario Presented by the Mexican Secretary of Energy for New Capacity 2016-2030

\begin{tabular}{|c|c|c|c|}
\hline & $\begin{array}{l}2015 \text { Composition of Total } \\
\text { Capacity: } 68,044.03 \text { MW }\end{array}$ & $\begin{array}{l}\text { 2016-2030 Composition of } \\
\text { New Capacity } 57,122.3 \mathrm{MW}\end{array}$ & $\begin{array}{c}\text { TOTAL CAPACITY } 2030 \\
\text { MW } 109,367.2 M^{*}\end{array}$ \\
\hline Combined Cycle (gas) & $\begin{array}{c}35.3 \% \\
24,019.54 \mathrm{MW}\end{array}$ & $\begin{array}{c}35.8 \% \\
20,449.78 \mathrm{MW}\end{array}$ & $\begin{array}{c}39.0 \% \\
42,642.70 \mathrm{MW}\end{array}$ \\
\hline $\begin{array}{l}\text { Coal-fired Power Plants }+ \\
\text { thermoelectric }\end{array}$ & $\begin{array}{c}26.6 \% \\
18,099.71 \mathrm{MW}\end{array}$ & $\begin{array}{c}2.0 \% \\
1,1142.45 \mathrm{MW}\end{array}$ & $\begin{array}{c}5.8 \% \\
6,342.40 \mathrm{MW}\end{array}$ \\
\hline Turbogas & $\begin{array}{c}7.2 \% \\
4,899.17 \mathrm{MW}\end{array}$ & -- & $\begin{array}{c}3.3 \% \\
3596.30 \mathrm{MW}\end{array}$ \\
\hline Combustion + others & $\begin{array}{c}2.6 \% \\
1,769.14 \mathrm{MW}\end{array}$ & -- & $\begin{array}{c}1.8 \% \\
1,992.83 \mathrm{MW}\end{array}$ \\
\hline TOTAL CONVENTIONAL & $\begin{array}{c}71.7 \% \\
48,787.57 \mathrm{MW}\end{array}$ & $\begin{array}{c}37.8 \% \\
21,592.23 \mathrm{MW}\end{array}$ & $\begin{array}{c}49.9 \% \\
54,574.23 \mathrm{MW}\end{array}$ \\
\hline Wind Energy & $\begin{array}{c}4.1 \% \\
2,803.41 \mathrm{MW}\end{array}$ & $\begin{array}{c}21.0 \% \\
12,000.00 \mathrm{MW}\end{array}$ & $\begin{array}{c}13.8 \% \\
15,101.10 \mathrm{MW}\end{array}$ \\
\hline Solar Projects & $\begin{array}{c}0.25 \% \\
170.24 \%\end{array}$ & $\begin{array}{c}12.0 \% \\
6,854.68 \mathrm{MW}\end{array}$ & $\begin{array}{c}6.3 \% \\
6,904.90 \mathrm{MW}\end{array}$ \\
\hline Nuclear Centrals & $\begin{array}{c}2.2 \% \\
1,469.97 \mathrm{MW}\end{array}$ & $\begin{array}{c}7.3 \% \\
41.69 .93 \mathrm{MW}\end{array}$ & $\begin{array}{c}5.2 \% \\
5,700.90 \mathrm{MW}\end{array}$ \\
\hline Hydroelectric Projects & $\begin{array}{c}18.4 \% \\
12,486.08\end{array}$ & $\begin{array}{c}7.9 \% \\
4,512.66 \mathrm{MW}\end{array}$ & $\begin{array}{c}15.5 \% \\
16,975.90 \mathrm{MW}\end{array}$ \\
\hline Geometric and Bioenergy & $\begin{array}{c}2.5 \% \\
1,701.1 \mathrm{MW}\end{array}$ & $\begin{array}{c}1.67 \% \\
953.94 \mathrm{MW}\end{array}$ & $\begin{array}{c}2,483.07 \% \\
2,483.07 \mathrm{MW}\end{array}$ \\
\hline Co-generation & $\begin{array}{c}0.88 \% \\
598.65 \mathrm{MW}\end{array}$ & $\begin{array}{c}12.3 \% \\
7,038.87 \mathrm{MW}\end{array}$ & $\begin{array}{c}7.0 \% \\
7,627.10 \mathrm{MW}\end{array}$ \\
\hline TOTAL RENEWABLE & $\begin{array}{c}28.3 \% \\
19,256.46 \text { MW }\end{array}$ & $\begin{array}{c}62.2 \% \\
35,530 \mathrm{MW}\end{array}$ & $\begin{array}{c}50.1 \% \\
54,792.97 \text { MW }\end{array}$ \\
\hline
\end{tabular}

*This figure includes the withdrawals and/or losses of electric power generation capacity.

Source: Elaborated with the data from SENER, 2016a

Hernandez-Martinez immediately called upon a meeting with his collaborators and expressed the following: "Indeed it is a great effort of the Mexican government to change the structure of the installed capacity in the utility industry, where renewable energy will go from $28.3 \%$ in 2015 to $50.1 \%$ in 2030." Some members of his team spoke up and asked: - "What role will this scenario play in the possibility of having more solar photovoltaic energy (PV)?; How is it possible, that wind energy will participate with 15,101.10 MW compared to the 6,904.90 MW of solar energy capacity in 2030?; Would it be possible to envision a change which could favor solar energy to wind energy towards 2030 ?"

Listening carefully to the debate, another collaborator referred to a research on this topic (Islas, 2009) and said that Mexico more than an oil country, is a country rich in renewable energy sources. It is, particularly, a solar country. A simple calculation could demonstrate that if we cover only $0.14 \%$ of Mexico's territory with photovoltaic solar cells, especially in the north where solar insolation is greater, Mexico could meet its current national requirements of electricity. The use of technologies and renewable resources would ensure self-sufficiency and energy security in the medium and long term, the opportunity to develop its own technologies, to create new industries with a significant amount of jobs, and to eliminate negative externalities (greenhouse gas emissions) currently generated in the Mexican electricity sector due to the use of fossil fuels. 
Others talked about a document on renewable energy, also presented by the Secretary of Energy (SENER, 2016b), which stated that the price of solar energy technology has decreased, becoming a new competitive renewable technology in the world.

Given this information and being aware that in the period 2008-2035, nearly 53\% of the world's energy demand will come from the generation of electricity (SENER, 2011), Hernandez-Martinez tasked a Solar Energy Committee to conduct an investigation into the solar photovoltaic industry. If electricity generation accounts for $32 \%$ of the world's consumption of fossil fuels and the generation of $41 \%$ of total $\mathrm{CO}_{2}$ emissions (IEA, 2010), changing the technologies used in electricity generation should be a central part of any effort to achieve reductions in global $\mathrm{CO}_{2}$ emissions. Mexico is indeed committed with the world in fostering the leadership of a new path of sustainable growth of its electricity sector.

To understand the importance of solar energy there are several national and international entities that are immersed in the desire to move the world into renewable energy (SENER, 2006). In Mexico, the support for solar energy growth comes from the Electrical Research Institute (IIE, 2010), the National Association of Solar Energy, the Mexican Association of Suppliers for Renewable Energy, and The National Commission for the Efficient Use of Energy (CONUEE), among others.

Therefore, the objective of the creation of the Solar Energy Committee within the CFE, will be to explore how the solar photovoltaic industry could become a possible and more important alternative source for electricity generation in the scenario presented by SENER (SENER, 2016a). Among its objectives is to present the advantages and disadvantages of solar energy generation and/or production, and the current dilemmas for its development in Mexico.

At the end of the session, Hernandez-Martinez asked himself: - "Could the results of this research change the scenarios for 2030 and make solar energy a more important player in the Mexican energy mix?"

\section{MEXICO IN THE WORLD SOLAR BELT}

After the formation of the Committee, Hernandez-Martinez went home and began to review some documents to refresh his knowledge about solar energy. According to the United Nations (1992), the power of solar radiation varies according to the latitude of the site, time of the day, and atmospheric conditions that could decrease or increase its power. It can be assumed that radiation power on the Earth's surface on a clear day, at noon, is close to $1,000 \mathrm{~W} / \mathrm{m}^{2}$ (watts per square meter). This power is known as "irradiance". During the day the solar irradiance varies according to the angle of the sun, the season of the year, the latitude, and the climate (UN, 1992). Therefore, it is necessary to have data on the insolation available at a specific place to design the optimal solar system for that spot. This process is called sizing of the system (structural dimensioning). If oversized, the system is more expensive than necessary and if undersized, it may not attract all the available irradiance at all times.

The usable solar radiation can be obtained directly, indirectly (diffused), or with the sum of both. Direct radiation is coming directly from the sun on a straight line without intermediate reflections or refractions; this radiation is like a beam and the easiest to capture for future use. The diffused radiation is the one that is absorbed by the atmosphere in clouds and other atmospheric and terrestrial elements and is radiated by the daytime sky, thanks to the phenomena of sun reflection and refraction.

Considering the amount of energy received from the sun, SENER (2012) states that Mexico has an average insolation of around $5.5 \mathrm{kwh} / \mathrm{m}^{2} /$ day (kilowatt-hour per $\mathrm{m}^{2}$ per day), which is a relatively high value. This value varies throughout the year according to the geographical location (especially latitude) and weather conditions in a given spot.

Hernandez-Martinez learned about some of the technological breakthroughs developed by Pedro Ponce Cruz, Director of the Master of Science in Engineering at Monterrey Tech, with the help of his Mechatronics students. They designed a special mechanism based on the efficient movement of solar cells using a solar magnetic optical tracker. The purpose of the solar tracker is to find the optimum position of solar cells for getting the maximum 
amount of radiation throughout the day. This product works with optimization algorithms which consider environmental factors, such as wind, to determine the right time to move and re-align the solar cells. This innovation with a beneficial effect on the environment, allows a better use of solar radiation with an increase of up to $35 \%$ of captured solar radiation.

SENER (2009) asserts that Mexico has favorable natural conditions for the application of photovoltaic systems. In many parts of the Mexican territory, the average solar radiation is twice that of European countries like Germany, which is currently one of the largest PV markets in the world. SENER also states that the immense potential of Mexico has been underexploited. By 2009, Mexico had only registered a capacity of approximately $25.1 \mathrm{MWp}$ (MWp =Megawatt peak), which is the highest potential for solar PV under ideal conditions of photovoltaic systems, compared to 3,800 MWp of installed capacity in Germany for the same year. Hernandez-Martinez asked himself: "What changes should be implemented in order to develop solar energy in Mexico?"

Kearney et al. (2010) presented a hope for the future development of photovoltaic solar energy in the world, especially for the countries located in what they call the Solar Belt (Sun Belt). In this study, an "accelerated scenario" estimated that these countries could increase their PV installed capacity to about 405 GW (Gigawatts) for the year 2030, taking the opportunity to provide sustainable electricity for about 300 million people (Mexico is expected to have $7 \mathrm{GW}$ of solar capacity for 2030). Mexico is located precisely in the Sun Belt which has a high propensity for a successful exploitation of PV. Furthermore, the analysis mentioned the most attractive countries for investment in PV: China, India, Australia, and Mexico. In second place other group of countries were identified: Turkey, Argentina, South Africa, Saudi Arabia, Egypt, and Thailand. In third place, developing countries like Kenya, Vietnam and the Philippines, as well as countries with high political risk as Angola, Yemen and Lebanon were identified.

Hernandez-Martinez was excited to realize that Mexico is located in the Sun Belt and asked himself: — "What are the advantages that Mexico presents compared with the other countries located in the Sun Belt? How is Mexico attracting investors for public and private investment in PV? Are Mexican reforms in energy enough to attract those investors to increase the PV infrastructure in Mexico?

To evaluate the attractiveness of Mexico for the exploitation of solar PV, there are some factors to be considered: projected growth in electricity consumption by 2030 , the competitiveness of PV compared with other available sources of electricity, distribution of electricity in the country, losses in transmission, flexible mix of energy sources, and the rate of electrification of the country (covered area with electricity networks).

Kearney et al. (2010) proposed another scenario for the countries located in the Sun Belt through a "paradigm shift" for electricity generation. They affirm that there is the possibility to generate up to $1,100 \mathrm{GW}$ of PV that would represent up to $12 \%$ of total power generation for some countries by 2030, where Mexico is expected to have only $6.3 \%$ of PV participation. In this scenario they expect a technological improvement by 2020 and a decrease of solar power costs for countries located in the Sun Belt. This would make solar energy more competitive than fossil fuel energy. In the long run, the authors are even more optimistic, expecting to be able to reach a lower cost level for solar energy for the year 2030. If this happens, PV would be even more competitive than the combined cycle power plants based on natural gas. A more recent study (Jäger-Waldau, 2013) projects that this downward trend will be kept towards 2033, making it a promising future for the world.

If photovoltaic technology takes off and achieves anticipated cost reductions, will the Mexican power grid be ready to make the transition to photovoltaic systems for years to come? Hernandez-Martinez expects that the new regulatory support under the 2013 Mexican energy reform could be helpful.

IEA (2009) estimates that around $80 \%$ of the expected world growth of electricity demand will come precisely from the countries located in the Sun Belt. The economic expansion of India and the Asiatic southeast could be supplied with solar energy (IEA, 2013).

Jacobson \& Delucchi (2009) reported that the viability of the world's electricity requirements could totally be supplied by 2030 as follows: $50 \%$ wind, $40 \%$ solar, $4 \%$ geothermal, $4 \%$ hydroelectric and $2 \%$ of the sea waves. 
They consider that nuclear, coal, ethanol, oil, and natural gas are poor options. Hernandez-Martinez asked himself: - "What are the conditions required to perform the transition proposed by Jacobson \& Delucci?; Is the world prepared with financial incentives and special management systems to optimize energy use during peak hours?" They pose the following dilemma: Is it possible to transform the global electricity system in just two decades? For them, the answer will depend on the technologies that are chosen, the availability of critical raw materials, and the economic and political factors.

Hernandez-Martinez remembered that Iceland is an example of hope where renewable energy provided almost $100 \%$ of electricity production in 2015: $73 \%$ from hydropower and 27\% from geothermal power. Thus, Iceland has become the world's largest green electricity producer in the world.

\section{SOLAR PHOTOVOLTAIC TECHNOLOGY}

Regardless of the passing of time, Hernandez-Martinez could not stop himself from digging through the documents on his desk in his home office. He realized that solar electricity is not ready for its use directly from nature. For this form of energy, men must design and develop appropriate conversion systems (Palz, 1978). Thus, he was eager to learn more on PV technology.

The photovoltaic effect is a physical phenomenon by which certain fabricated devices (photovoltaic cells) function as semiconductors and are capable of converting sunlight into electricity without any intermediate process.

A photovoltaic cell has the primary function to convert energy captured from the sun into electricity at the atomic level; many of them have a property known as the photoelectric effect which makes light photons to be absorbed in order to irradiate electrons later, which once captured, generate an electric current that is used as electricity by conversion. Albert Einstein described the photoelectric effect, which is the fundament of actual photovoltaic technology; his work awarded him the Physics Nobel Prize in 1921 (Energia Solar, nd).

Photovoltaic cells, also known as solar cells, are made of semiconductor materials, especially silicon, the same material used in the microelectronic industry. A thin semiconductor wafer is used to cause a positive electric field on one side and a negative on the other; when the sunrays reach the photovoltaic cell, electrons are knocked loose from the atoms in the semiconductor material to generate electricity.

A photovoltaic panel is formed with a group of cells. An arrangement of several electrically connected panels in a structure, generates a photovoltaic module. Photovoltaic systems can operate in isolation (rural areas) or connected to the electricity grid. With regard to the latter, they interact with the network via an electronic interface (inverter) which converts the direct current into a photovoltaic array of alternate current.

The urban-type solar PV system is one that is connected to the network of CFE and is used in cities in order to lower the utility bill paid to the state owned electricity company (CFE). These solar systems are silent, have no moving parts and only eventually require cleaning to ensure that the sun's rays penetrate properly. The sun's rays are converted to direct current which is then converted to alternate current in an inverter. This inverter synchronizes the voltage and frequency with CFE network to be delivered at the citizen's residence in a transparent and stable way. If the system is delivering more energy than the required for consumption, it will go back to the CFE network meter spinning in reverse. In short, this system uses the CFE as a temporary energy storage who returns energy at night or when there is no sunlight, saving the user the investment and the installation of a battery bank which is usually costly and polluting (Powerstein, 2010). For this scheme to work, it is required to establish a two-way contract that must be processed by the CFE.

The rural type solar PV system is used in places far from the CFE network and need a battery bank to store energy. The sun's rays are converted to direct current which is stored in those batteries and then the energy would be converted to AC (alternate current) in the inverter that simulates the type of energy that would be delivered by the CFE. 
Silicon is the main material used in the PV systems, and most of the photovoltaic devices are made of crystalline silicon (UN, 1992). There are two types of crystalline silicon: a monocrystalline (single crystal) and a polycrystalline (multicrystalline or semicrystalline).

PV systems are currently feasible for places far from the grid, for electrification, rural telephony, and pumping water, among others. They have the following advantages (World Bank, 1995): installation speed, easy dismantling of the plant once it has finished its useful life, easy maintenance (can be serviced without closing the plant as it is driven by solar modules), with the benefit of operational improvements and lower maintenance costs.

$\mathrm{PV}$ is already playing an important role in the generation of electricity around the world. This is due to the fact that the fast decrease in costs of this technology has made the non-subsidized PV a competing technology with those that use fossil fuels (SENER, 2016b).

As Palz (1978) confirms, the development of the applications of solar energy does not mean the beginning of a new economic world; on the contrary, the new energy systems must win their place in the entire energy market first, by being competitive with oil, coal, gas, or nuclear power, either by depletion of conventional sources (non-renewable resources will eventually be exhausted and no country can rely on them indefinitely), due to lower chemical contamination of the environment, looking for a greater independence from foreign countries, or just because of their lower costs.

SENER (2009) forecasted that in a period of 3 to 5 years PV systems in several regions of Mexico are going to become profitable, by decreasing prices, resulting in higher sales volume and making market niches more attractive. Hernandez-Martinez asked himself: - "If they are right, what are we doing to exploit this available renewable energy source?"

\section{FINANCIAL STRATEGY FOR THE DEVELOPMENT OF PV}

Palz (1978) recommends that a country should promote their "inner energy sources" even when they are more expensive than imported energy for two reasons. Firstly, since energy is an important input in the economy, the trade balance could be adversely affected if the share of imported energy is too large. Secondly, if energy imports were restricted, the economy's growth could be hindered; thus, importing energy means economic vulnerability.

Likewise, Palz (1978) provides the criteria for the development of a long-run energy policy: granting independence from foreign supply, securing long term availability at reasonable prices, decreasing pollution, and keeping environmental purity. He also points out that energy should be both, comfortable in its transport and use. One might say that solar energy has no drawbacks, the heat balance of the earth is not altered and it is universally accepted.

The Secretary of Energy in Mexico (SENER, 2011) was aware of the importance of implementing short-term actions that can generate a national energy transition, meaning a radical change in the way in which it is obtained and consumed, as well as to enable the country with the reduction of greenhouse gas emissions, mitigating the environmental impact of the sector and helping to combat the effects of climate change.

Hernandez-Martinez proudly said to himself: - "Mexico excels in the world for its commitments with the most ambitious targets in electricity generation with renewable resources." Thus, Mexico has taken various actions and initiatives, using the criterion of sustainability as a central focus. It is noteworthy that the Law on the Use of Renewable Energies and Financing of the Energy Transition (Ley para el Aprovechamiento de las Energias Renovables y el Financiamiento de la Transicion Energetica), published in the Official Gazette (Diario Oficial de la Federacion) on November 28, 2008, clearly established the target of $35 \%$ of electricity generated through renewables by 2024. Its commitment includes not only the regulation but the financing process of this energetic transition.

The Trust Fund CONACYT-SENER-Energy Sustainability was established to foster scientific research and applied technology for renewable energy sources, energy efficiency, clean technologies, diversification of sources of primary energy, and the adoption, innovation, assimilation and development of technology in these areas. 
SENER, supported by the World Bank, promoted projects that encourage a national policy for rural electrification with renewable energies.

The national institutions that provide financing for the development of renewable energy are: Mexican Bank for Foreign Trade (BANCOMEXT), National Council for Science and Technology (CONACYT), SENER (Mexican Secretary of Energy) and NAFIN (Nacional Financiera); among the international ones are: World Bank, InterAmerican Development Bank, Global Environment Facility (GEF) and the European Investment Bank. Undoubtedly, private financing is also a major component to trigger financing projects in clean technologies.

\section{SOLAR ENERGY AS THE PEACEMAKING HOPE AMONG NATIONS}

As Hernandez-Martinez stood up from his chair holding a cup of coffee, he imagined a peaceful world based on solar energy. He asked himself: - "Will the energy and electricity reforms in Mexico provide the adequate regulatory reform in order to actively support the development of promising solar energy in the country?"

If Mexico is one of the countries located in the Sun Belt and its potential is extraordinary, Hernandez-Martinez prepared a list of questions to guide the research of the Solar Energy Committee:

- What should the government and CFE do to promote PV in the search for the optimal energy mix and the promotion of long-term investment?

- What incentives need to be designed to take advantage of the strengths offered by photovoltaics systems?

- What is the best way to exploit photovoltaics: connected to the national grid or developed by independent producers?

- What kind of political support needs to be given to the development of solar PV to contribute to the economic development of Mexico?

- Could the support for investments in photovoltaic cells promote the generation of new jobs through the development of supplying services associated with the production of this renewable energy?

- How willing should the Mexican economy be to open its market for developing photovoltaics through collaboration agreements with other countries who have major advances in this technology?

- How should Mexico support the development of its own photovoltaic cells' technology?

- How should financial mechanisms for both private banks and development banks be developed to encourage the growth of solar photovoltaic technology in Mexico?

- How could Mexico promote the transfer of technological breakthroughs from advanced markets in photovoltaic technology?

- Within the Mexican energy reform, is there any specific mention of the development of solar energy?

- Should Mexico create a new independent institution to be in charge of the solar energy development?

- What is the real status of solar energy development in Mexico?

- What could we learn from those which are already walking through the sustainable electricity path of solar energy?

- Who will remove the brake to the countries located in the Sun Belt to develop the full potential that solar photovoltaics offer?

- What should be a visionary approach in the design of economic policies to incentive the transition into new paradigms in the generation of electricity?

- What could be the public and private commitments for the revolution of electricity generation through the emergence of a new photovoltaic power generation?

In a world context vision, Palz (1978) states that the solar energy received on earth for the period of a year is 10 times larger than the total energy from fossil fuels. While solar energy is equally distributed, fossil fuels are located in an unequal geographical distribution among countries, concentrating mostly in the Middle East. PV represents a hope for each country offering more potential energy than needed, renewed annually by the sun. The opportunity to exploit this energy source is to visualize it as a "homemade reserve" that exists in all areas of the world. Only those countries that undertake the necessary efforts to develop techniques for processing it, will enjoy this gift from 
nature. Therefore Palz (1978) insists that compensating the inequalities caused by the distribution of fossil fuel resources, solar energy holds out the hope for a better balance between nations.

There is an urgent need to study the long-term energy outlook for every country, not to mention that energy programs are inevitably also immersed in a political dimension.

It is essential to evaluate the possibility of redesigning a strategy to support the transition in Mexico from an unsustainable power generation system to one based on more renewable energy where PV could be a key game changer for 2030. Hernandez-Martinez eagerly awaits the report of the Solar Energy Committee in order to better understand the dilemmas of solar energy in Mexico and clarify them before the Honorable Mexican Congress to promote a more intensive PV participation in the future Mexican energy mix.

\section{QUESTIONS AND INSTRUCTIONS}

1. Consider every student a member of the Solar Energy Committee, asking them to answer the list of questions prepared by the Director of CFE helping him clarify his dilemma: "How to increase the electric power required for economic development through clean technologies where solar technologies could made up a bigger share in the energy mix?"

2. This is a dilemma faced by every country. The professor could choose to apply this dilemma to any country of the world, proposing an ethical framework for the chosen country. There is no right or wrong answer, as long as the student prepares a coherent research on the topic.

3. Trigger team work by suggesting the definition of an Action Plan to follow in order to solve the case; consider the students as consultants who could assume different roles in the debate as follows:

a. Finance \& Economic Consultant

b. Energy Consultant

c. Political \& Legal Consultant

d. Technological \& Innovations Consultant

e. Ethics \& Citizenship Consultant

4. Students will determine the Action Plan for each of these roles. In which aspects do they agree? In which aspects do they disagree?

5. They will finally establish a Final Solution Proposal that summarizes the objectives of all the consultants' Action Plans.

Suggested Courses: Economics of Natural Resources, Business Ethics, International Finance, Financial Institutions, Case Studies in Business.

AUTHOR BIOGRAHIES

Flory Dieck-Assad, PhD in Finance from Tulane University, USA 2003. Author of "Financial Institutions" by McGraw-Hill in 2003, and second edition in 2014. With over 200 publications in refereed journals and magazines of national and international scope, is member of the National System of Researchers since December 2005 to date; "Texas A \& M University Press" published in 2005 her second book "Energy and Sustainable Development in Mexico", honored with the Romulo Garza Award 2007 with its second printing in 2008. Awarded with the Prize for Teaching \& Research 2007, 2010 and 2014; the National Ethics Award 2013, the 2015 Distinguished Professor of the Institute of Chartered Accountants of the State of Nuevo Leon, Mexico, and the 2015 National Energy Prize for her contributions to the energy sector. Tenured professor at Tecnologico de Monterrey. E-mail: fdieck@itesm.mx (contact author).

Eduardo Carbajal-Huerta, PhD in Business Administration from Tecnologico de Monterrey, Mexico, major in Finance from University of Texas at Austin, worked as Director of Financial Planning within Tecnologico de Monterrey, and as Dean in the Peru headquarters. He has taught in Mexico, Dominican Republic, and Peru, as well as in the Global MBA program from Thunderbird School of Global Management, in graduate and undergraduate courses with majors in International Finance, Economics of Natural Resources, Macroeconomics, and the Stock Market. His published papers in renowned editorials in Mexico, in Economic Growth and Finance, have been presented in international conferences in Spain, Brazil, Colombia, and Mexico. Research Associate Professor at 
Tecnologico de Monterrey, member of the Academy of Economists and the Mexican Institute of Finance Executives.

\section{REFERENCES}

Canal del Congreso (2016). Comparece titular de Sener ante Comisión de Energía en Cámara Baja. Retrieved from: http://www.canaldelcongreso.gob.mx/noticias/9360/Comparece_titular_de_Sener_ante_Comision_de_Ener gia_en_Camara_Baja

Energia Solar (nd). Celdas fotovoltaicas: historia. Retrieved from: http://www.instalacionenergiasolar.com/energia/celdas-fotovoltaicas.html.

IEA (2009). World Energy Outlook, International Energy Agency.

IEA (2010). Energy technology perspectives 2010, International Energy Agency, OCDE/AIE, Paris France.

IEA (2013). World Energy Outlook, International Energy Agency.

IIE (2010). Instituto de Investigaciones Eléctricas (IIE). Retrieved from: http://www.iie.org.mx, http://www.iie.org.mx/proyectofotovoltaico/preguntas.php; http://www.iie.org.mx/proyectofotovoltaico/acerca_de.php;

Islas, J. (2009). Los dispositivos de fomento para la inserción de las fuentes renovables de energía en los sectores eléctricos, in the book La Energía en México: Situación y Alternativas, coordinated by John Saxe Fernández, Centro de Investigaciones Interdisciplinarias en Ciencias y Humanidades, Universidad Nacional Autónoma de México, Colección El Mundo Actual, México, First Edition.

Jacobson, M. Z. \& Delucchi, M. A. (2009). A Plan to Power 100 Percent of the Planet with Renewables, Scientific American, November 1. Retrieved from: November 2009 issue of Scientific American.

Jäger-Waldau, Arnulf (2013). PV Status Report 2013, Renewable Energy Mapping in Europe and Africa (REMEA), Joint Research Centre, European Commission: Retrieved from: http://iet.jrc.ec.europa.eu/remea/pv-statusreport-2013

Kearney, A.T., Hauff, J., Vedonck, M., Derveaux, H., Dumarest, L., Alberich, J. \& Malherbe, J-C. (2010). Unlocking the Sunbelt Potential of Photovoltaics, second edition, October, European Photovoltaic Industry Association.

Palz, W. (1978). Electricidad Solar: Estudio Económico de la Energía Solar, Editorial Blume, UNESCO.

Powerstein (2010). Retrieved from: http://www.powerstein.com.mx

SEIA (Solar Energy Industries Association) (2017a). Solar PV sets a record in 2016 and is top choice for new generating capacity, Energize Weekly, Vol. 9, Issue 12. Retrieved from: https://www.euci.com/solar-pvsets-a-record-in-2016-and-is-top-choice-for-new-generating-capacity/

SENER (2006). Energías Renovables para el Desarrollo Sustentable en México. Retrieved from: http://www.energia.gob.mx

SENER (2009). Nichos de mercado para sistemas Fotovoltaicos en conexión a la red eléctrica en México, Forever Print S.A. de C.V., México.

SENER (2011). Estrategia Nacional para la Transición Energética y el Aprovechamiento Sustentable de Energía, Secretaría de Energía, Mexico.

SENER (2012). Prospectiva de Energías Renovables 2012-2026, Secretaría de Energía, Mexico.

SENER (2016a). Prospectiva del Sector Electrico 2016-2030, Mexico.

SENER (2016b). Prospectiva de Energias Renovables 2016-2030, Mexico.

UN (United Nations) (1992). La conversión directa de energía solar en electricidad, Departamento de Desarrollo Económico y Social, Nueva York.

World Bank (1995). The Case for Solar Energy Investments, World Bank Technical Paper Number 279, Energy Series, Washington, D.C. 


\section{NOTES}

